\title{
Demonstration of papilloma virus particles in cervical and vaginal scrape material: a report of 10 cases
}

\author{
CYNTHIA M STANBRIDGE, JEAN MATHER, ALAN CURRY, E BLANCHE \\ BUTLER
}

From the Cytology Laboratory, St Mary's Hospital, Manchester M13 OJH, and the Public Health Laboratory, Withington Hospital, Manchester

SUMMARY The finding of virus particles by transmission electron microscopy (TEM) in fixed $\underset{\oplus}{\omega}$ cervical and vaginal scrape material and their identification as papilloma viruses by negative staining $\dot{i r}_{j}$ is described.

The colposcopic, cytological, and histological appearances in a group of 10 patients in whomo virus particles were seen are discussed and the possibility considered of an association between $\rightarrow$ papilloma virus infection and the development of cervical intraepithelial neoplasia (CIN) and multi- 3 focal intraepithelial neoplasia of the female lower genital tract.

Using thin sectioning and negative staining, virus particles, considered to be papilloma viruses, have been demonstrated in vulval warts by transmission electron microscopy. ${ }^{1}$ Similar virus particles have been seen in thin sections of cervical condylomatous lesions using transmission electron microscopy. ${ }^{2-4}$ The association of condylomatous lesions of the cervix with intraepithelial neoplasia has been reported by a number of workers ${ }^{4-8}$ and virus particles have been demonstrated in non-papillary lesions ${ }^{2} 3$ which were found to be flat condylomas on histological section. ${ }^{6}$ These cases showed cytological features seen in patients with clinical condylomata and cells removed from cytology smears have been found to contain virus particles. ${ }^{9} 10$

Papilloma virus particles have been identified in material scraped from the surface of vulval warts ${ }^{1}$ but as far as we are aware they have not been described in cervical or vaginal scrape material. This report describes the finding of virus particles in fixed cervical and vaginal scrape material by transmission electron microscopy and the confirmation by negative staining of similar scrape material, in two cases, that these were papilloma viruses. The association with cervical intraepithelial neoplasia is also considered.

\section{Materials and methods}

Since 1975 cellular samples for transmission electron microscopy (TEM) have been collected into gluter-

Accepted for publication 30 September 1980 aldehyde or similar fixative from most of the patients. who attended the colposcopy clinic at St Mary'so Hospital, Manchester and during 1979 additional cellular samples have been collected into saline. Samples were prepared for TEM as previouslyo described. ${ }^{11}$

Material collected into saline was stored at $-20^{\circ} \mathrm{C} \overrightarrow{\hat{O}^{\prime}}$ and only examined if virus particles were seen in 3 fixed material. In two such cases a saline sample was available and, after freeze-thawing several times to rupture the cells, the sample was centrifuged to응 remove large cell debris at $3000 \mathrm{rpm}(3000 \mathrm{~g})$ for $30^{\circ}$ minutes. Two $\mathrm{ml}$ of the supernate were further. centrifuged at $30000 \mathrm{rpm}(65000 \mathrm{~g})$ for one hour in an ultracentrifuge (MSE Superspeed 65). The 3 supernate was discarded and the remaining pelleto resuspended in two to three drops of distilled water A drop of resuspended pellet was dried on to ao formvar-carbon coated grid, stained with $3 \%$ phosphotungstic acid (pH 6.5) and examined ino either an AEI EM 801 or EM 6B calibrated electron N microscope.

In two cases where virus particles were seen, ${ }_{\sigma}^{\omega}$ histological blocks of formalin-fixed biopsy materiak were dewaxed and processed for electron microscopy The areas required were cut from the blocks, excesse wax removed and the tissues placed in an incubator at $60^{\circ} \mathrm{C}$ in order to melt most of the remaining wax This process was completed by immersion in xyleneD and after rehydration through decreasing strengths of alcohol to water, the specimen was processed for electron microscopy as previously described for cellular material. ${ }^{11}$ Thick sections $(1 \mu)$ were cut $\delta$ 
stained with $1 \%$ toluidine blue and examined by light microscopy to confirm that suitable tissue had been selected before cutting ultra-thin sections for examination with the electron microscope.

\section{Results}

From 1975 to 1979 (inclusive), cellular samples for TEM were collected from 570 patients and during 1979 paired samples were collected into saline from 158 patients. The material from 50 patients has so far been screened by TEM for intranuclear virus particles and these were selected at random from the total collection. Virus particles have been seen in 10 cases, nine were cervical scrape specimens and one was collected from the vaginal vault. In two patients (cases 6 and 9 in Table 4) material collected into saline was available and negative staining in both cases demonstrated virus particles morphologically compatible with papilloma virus.

\section{MORPHOLOGY}

TEM: In thin sections the nuclear particles seen in the electron micrographs were approximately $40 \mathrm{~nm}$ in diameter. They consisted of a dense core surrounded by a less dense halo (Fig. 1). Very few cells in each sample contained virus particles; sometimes only one cell in up to 50 examined. Virus particles were seen in the cytoplasm as well as in the nucleus in occasional cells with very degenerate, fragmented nuclei, otherwise two types of nucleus containing virus particles were observed. In one group the

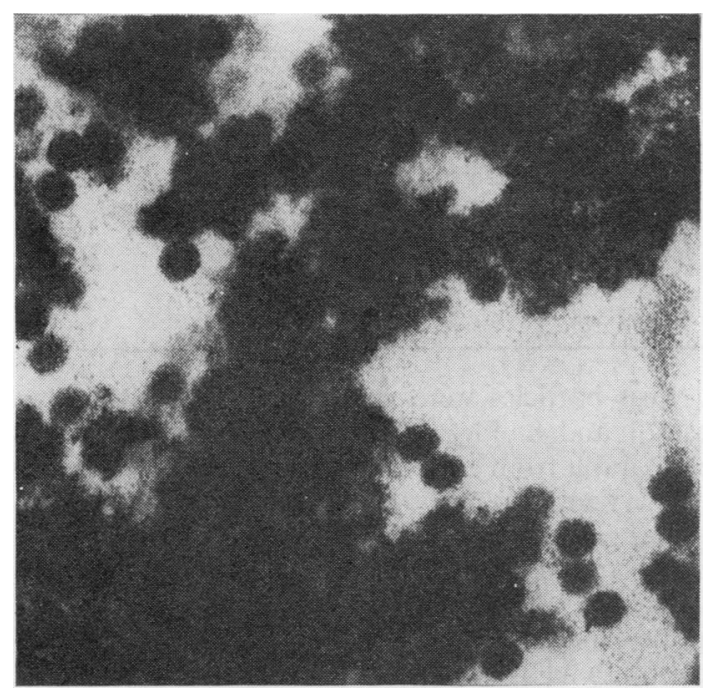

Fig. 1 Electron micrograph showing virus particles with dense core and surrounding less dense halo. Uranyl acetate and lead citrate $\times 112500$ nuclei showed margination of chromatin with large central clear areas in which virus particles could be seen easily (Fig. 2) while in the other group the

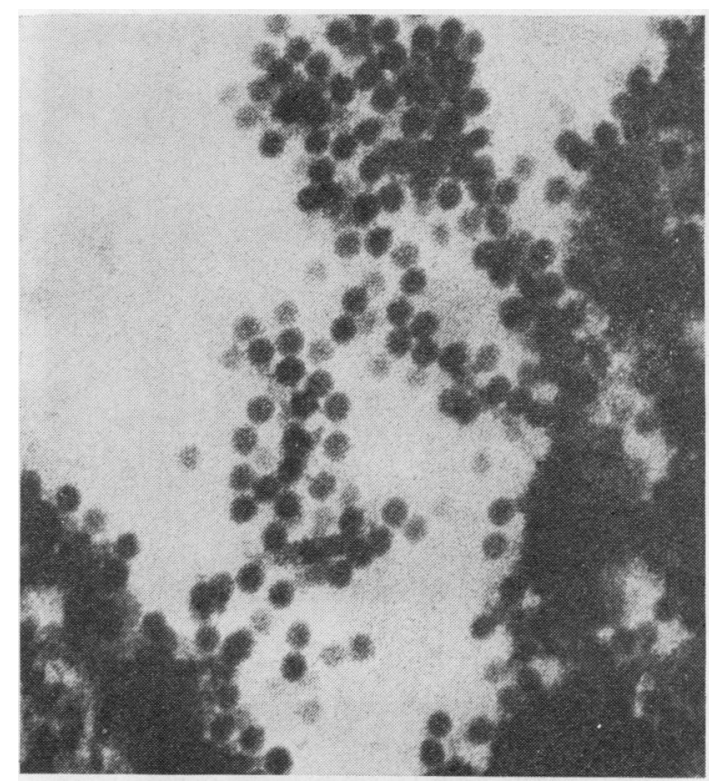

Fig. 2 Part of nucleus showing margination of the chromatin and central "empty" areas containing easily visible virus particles. Uranyl acetate and lead citrate $\times$ 62500

nuclei were electron opaque with large dense masses of chromatin. In this type of electron dense nucleus virus particles were more numerous and closely packed which made them more difficult to see (Figs 3a and b).

Negative staining: Virus particles were found in both of the cases examined (Fig. 4). These were morphologically identical to papilloma viruses and measured 50-62 $\mathrm{nm}$ in diameter in a calibrated electron microscope.

\section{CLINICAL DETAILS}

The colposcopic findings, cytological features and histological reports in the 10 patients with intranuclear virus particles (group A) and in the $\mathbf{4 0}$ patients without intranuclear virus particles in cellular scrape material (group B) are shown in Tables 1, 2 and 3. It can be seen that the groups are similar. It is not unexpected that proportionately more patients in group A show features which suggest a virus infection, for example eight of the 10 patients in group A show koilocytosis in tissue as compared with only 16 of the patients in group B. Four cases of invasive carcinoma occurred in group 

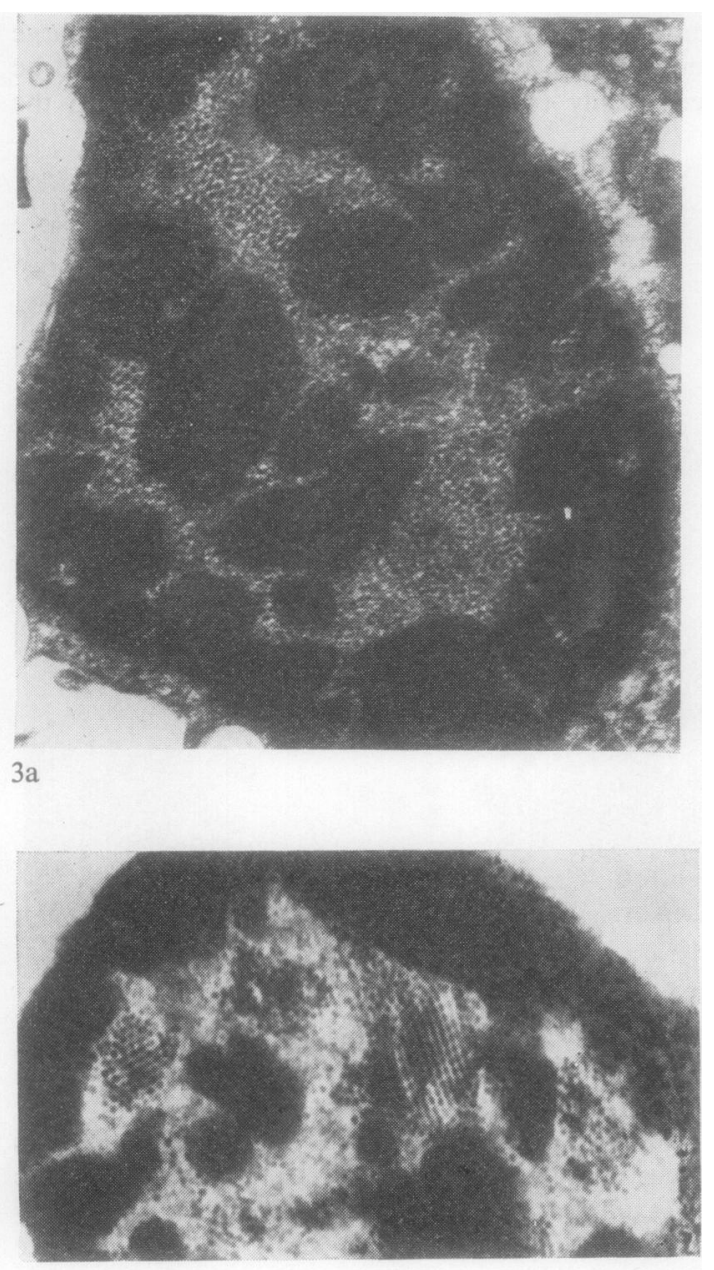

$3 b$

Fig. 3 (a) Case 10. Electron micrograph showing nucleus with large masses of chromatin and dense concentration of virus particles. Uranyl acetate and lead citrate $\times 25$ 000. (b) Case 6. Nucleus with large masses of chromatin and numerous virus particles showing crystalline array. Uranyl acetate and lead citrate $\times 25000$

B, two of these were squamous cell carcinoma with nothing to suggest an overt virus infection, the third had a microinvasive carcinoma with koilocytosis in adjacent non-invasive epithelium and the fourth patient had an adenoid cystic carcinoma of the cervix with a separate condyloma of the cervix.

The age range was also similar; in group $\mathbf{A}$ this was 18 to 55 years and in group B 17 to 69 years.

The patients in group A are considered in greater depth and details of each case are given in Table 4. The following observations are of interest:

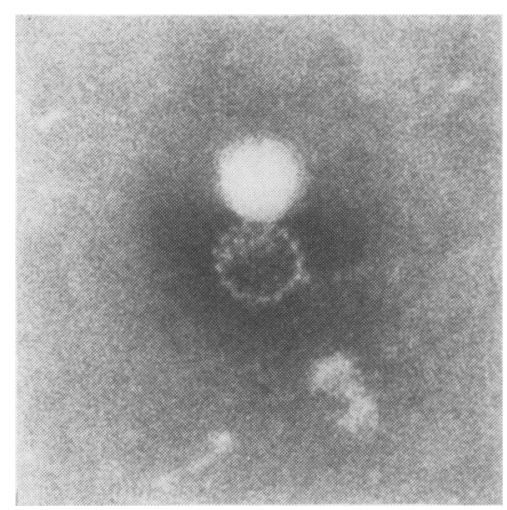

Fig. 4 Case 6. Negatively stained material showing papilloma virus particle. Phosphotungstic acid $\times 150000+$

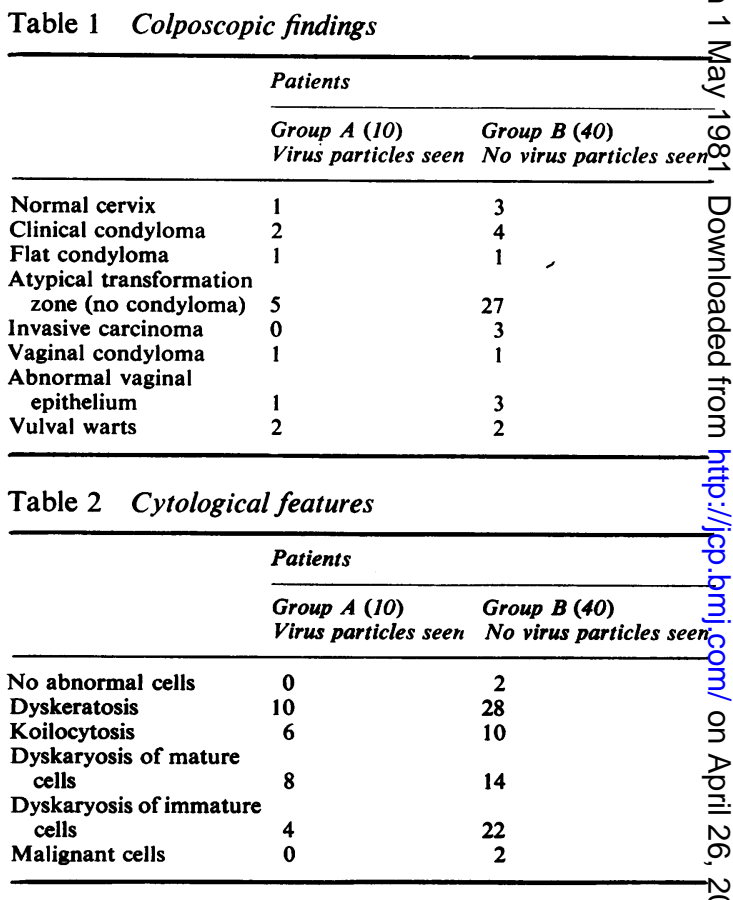

1. Virus particles were seen in cervical tissue froma cases 1 and 8. Fig. 5 shows part of the electrong micrograph from case 1 and virus particles are seew with crystalline array. This patient was immuno suppressed having had a renal transplant and she had a large condyloma of the cervix: there was noo evidence of CIN. Case 8 presented with koilocytosi? in the smear together with dyskaryotic cells. Ex@ amination of the tissue showed CIN I, II and II $\vec{g}$ with areas of koilocytosis but no condyloma. Virus particles were seen in superficial cells in a section of the epithelium reported as CIN II. As in the case of 
Table 3 Histological reports. (The most important lesions seen in colposcopic biopsy, cone biopsy, or hysterectomy are indicated)

\begin{tabular}{lll}
\hline & \multicolumn{2}{l}{ Patients } \\
\cline { 2 - 3 } & $\begin{array}{ll}\text { Group A (10) } \\
\text { Virus particles seen }\end{array}$ & $\begin{array}{c}\text { Group B }(40) \\
\text { No virus particles seen }\end{array}$ \\
\hline Inadequate biopsy & 1 & 0 \\
Negative & 0 & 7 \\
Condyloma & 3 & 4 \\
Koilocytosis in tissue & 8 & 16 \\
*CIN I & 2 & 6 \\
*CIN II & 3 & 5 \\
*CIN III & 2 & 16 \\
Invasive carcinoma & 0 & 4 \\
\hline
\end{tabular}

*Cervical intraepithelial neoplasia. cellular material very few cells in the sections contained virus particles, in case 8 three tissue blocks were examined before a nucleus containing virus particles was found.

2. Koilocytosis was not always seen in the cervical smear even when a clinically obvious condyloma was present. This is illustrated by cases 1 and 2 and the observation is explained when sections of the lesion are examined. In both cases koilocytotic cells were in the mid-zone of the epithelium and there was marked parakeratosis at the surface (Fig. 6). When koilocytotic cells were prominent in the cervical smear these were found to be at the surface in the tissue sections. This is seen in Figs $7 \mathrm{a}$ and $7 \mathrm{~b}$

Table 4 Analysis of cases with intranuclear virus particles

\begin{tabular}{|c|c|c|c|c|c|c|c|}
\hline \multirow{3}{*}{\multicolumn{2}{|c|}{ Case No. and age }} & \multirow[t]{3}{*}{ Colposcopic findings } & \multicolumn{4}{|c|}{ Cytological features } & \multirow[t]{3}{*}{ Histological reports } \\
\hline & & & \multirow[t]{2}{*}{ Dyskeratosis* } & \multirow[t]{2}{*}{$\boldsymbol{K A} \dagger$} & \multicolumn{2}{|l|}{ Dyskaryosis } & \\
\hline & & & & & Mature & Immature & \\
\hline 1 & $\begin{array}{l}32 \\
\text { Renal transplant }\end{array}$ & $\begin{array}{l}\text { Florid cervical warts (typical } \\
\text { papillary condylomata); } \\
\text { previous vulval warts }\end{array}$ & ++ & Nil & Nil & Nil & $\begin{array}{l}\text { Cone biopsy-condyloma } \\
\text { acuminatum }\end{array}$ \\
\hline 2 & 39 & Almost flat condyloma anterior lip & + & Nil & Nil & Nil & $\begin{array}{l}\text { Colposcopic biopsy-condyloma } \\
\text { acuminatum }\end{array}$ \\
\hline 3 & $\begin{array}{l}18 \\
\text { Pregnant }\end{array}$ & $\begin{array}{l}\text { Florid cervical warts (typical } \\
\text { papillary condylomata) and } \\
\text { vulval warts }\end{array}$ & + & Slight & $\begin{array}{l}\text { Slight with } \\
\text { multinucleation }\end{array}$ & Nil & $\begin{array}{l}\text { Colposcopic biopsy-inadequate } \\
\text { biopsy }\end{array}$ \\
\hline 4 & 20 & $\begin{array}{l}\text { Flat, atypical transformation zone } \\
\text { with mosaic pattern; multiple } \\
\text { warts (papillary condylomata) in } \\
\text { fornices and vulval warts }\end{array}$ & \pm & Slight & $\begin{array}{l}\text { Slight with } \\
\text { multinucleation }\end{array}$ & $\begin{array}{l}\text { Occasional, } \\
\text { slight }\end{array}$ & $\begin{array}{l}\text { Colposcopic biopsy-typical flat } \\
\text { condyloma adjacent to moderate } \\
\text { dysplasia (CIN II) }\end{array}$ \\
\hline 5 & 31 & $\begin{array}{l}\text { Peripheral raised area with } \\
\text { punctation anterior lip; squamo- } \\
\text { columnar junction visible }\end{array}$ & + & + & $\begin{array}{l}\text { Slight with } \\
\text { multinucleation }\end{array}$ & $\begin{array}{l}\text { Occasional, } \\
\text { slight }\end{array}$ & $\begin{array}{l}\text { Colposcopic biopsy-mild dysplasia } \\
\text { with marked koilocytosis (surface } \\
\text { in places) (CIN I) }\end{array}$ \\
\hline 6 & 27 & $\begin{array}{l}\text { Atypical, flat transformation zone } \\
\text { with focal hyperkeratosis }\end{array}$ & \pm & $\mathrm{Nil}$ & $\begin{array}{l}\text { Slight to moderate } \\
\text { with } \\
\text { multinucleation }\end{array}$ & Nil & $\begin{array}{l}\text { Colposcopic biopsy-mild to } \\
\text { moderate dysplasia with marked } \\
\text { koilocytosis, mid epithelium } \\
\text { (CIN I-II) } \\
\text { Cone biopsy-mild dysplasia with } \\
\text { acanthosis and parakeratosis } \\
\text { (CIN I) }\end{array}$ \\
\hline 7 & 45 & $\begin{array}{l}\text { Large ectopy with surrounding } \\
\text { atypical, aceto-white and } \\
\text { Schiller positive transformation } \\
\text { zone }\end{array}$ & + & Nil & $\begin{array}{l}\text { Slight to moderate } \\
\text { with } \\
\text { multinucleation }\end{array}$ & $\begin{array}{l}\text { Slight to } \\
\text { moderate }\end{array}$ & $\begin{array}{l}\text { Colposcopic biopsy-mild dysplasi } \\
\text { without koilocytosis (CIN I) } \\
\text { Hysterectomy-mild dysplasia with } \\
\text { koilocytosis extending to surface } \\
\text { in places (CIN I) }\end{array}$ \\
\hline 8 & 55 & $\begin{array}{l}\text { Large atypical, aceto-white and } \\
\text { Schiller positive transformation } \\
\text { zone; flat warty areas seen post } \\
\text { cone biopsy } 6 \text { months after } \\
\text { collecting cellular scrape } \\
\text { material }\end{array}$ & + & ++ & $\begin{array}{l}\text { Slight to moderate } \\
\text { with marked } \\
\text { multinucleation }\end{array}$ & Nil & $\begin{array}{l}\text { Colposcopic biopsy-mild dysplasi } \\
\text { with marked surface koilocytosis } \\
\text { (CIN I) } \\
\text { Cone biopsy-moderate to severe } \\
\text { dysplasia, no koilocytosis in thes } \\
\text { areas (CIN II-III) } \\
\text { Hysterectomy-moderate dysplasia } \\
\text { with koilocytosis (CIN II) }\end{array}$ \\
\hline s & $\begin{array}{l}55 \\
1960 \text { cervical } \\
\text { carcinoma in } \\
\text { itu (hysterectomy) } \\
\text { 970 vulval } \\
\text { carcinoma in } \\
\text { itu (local excision) } \\
978 \text { vulvectomy } \\
\text { evere dysplasia } \\
\text { Hyperkeratosis of } \\
\text { ntroitus }\end{array}$ & $\begin{array}{l}\text { Hyperkeratotic, Schiller positive } \\
\text { epithelium right side of vault }\end{array}$ & $\begin{array}{l}++ \text { with } \\
\text { anucleate } \\
\text { squames }\end{array}$ & + & Slight & Nil & $\begin{array}{l}\text { Colposcopic biopsy vault-on } 6 \\
\text { occasions, mild to moderate } \\
\text { dysplasia with hyper and } \\
\text { parakeratosis. Surface } \\
\text { koilocytosis in } 1 \text { biopsy not } \\
\text { showing hyperkeratosis (CIN I-II }\end{array}$ \\
\hline 10 & $\begin{array}{l}26 \\
\text { Julval warts } 7 \text { yrs }\end{array}$ & $\begin{array}{l}\text { No abnormality of ectocervix; } \\
\text { vulva thick epithelium with } \\
\text { punctation }\end{array}$ & ++ & Slight & $\begin{array}{l}\text { Slight to moderate } \\
\text { with } \\
\text { multinucleation }\end{array}$ & $\begin{array}{l}\text { Slight to } \\
\text { moderate }\end{array}$ & $\begin{array}{l}\text { Cone biopsy-severe dysplasia and } \\
\text { carcinoma in situ in canal (CIN II } \\
\text { Vulvectomy-severe dysplasia and } \\
\text { carcinoma in situ with viral } \\
\text { changes }\end{array}$ \\
\hline & $=$ moderate & $\begin{array}{l}=\text { extensive } \\
\text { ypia }\end{array}$ & & & & & $\begin{array}{l}\text { CIN = cervical intraepithelial } \\
\text { neoplasia }\end{array}$ \\
\hline
\end{tabular}




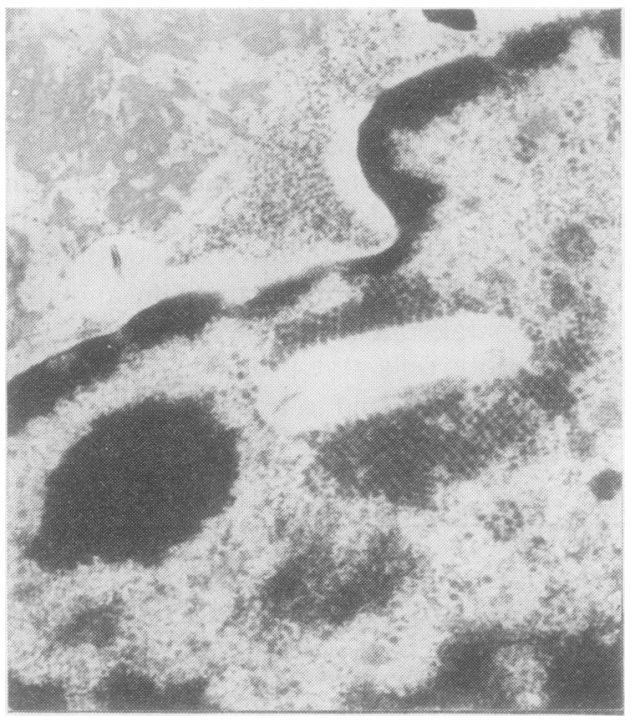

Fig. 5 Case 1. Electron micrograph of dewaxed cone biopsy material showing virus particles with crystalline array. Uranyl acetate and lead citrate $\times 25000$

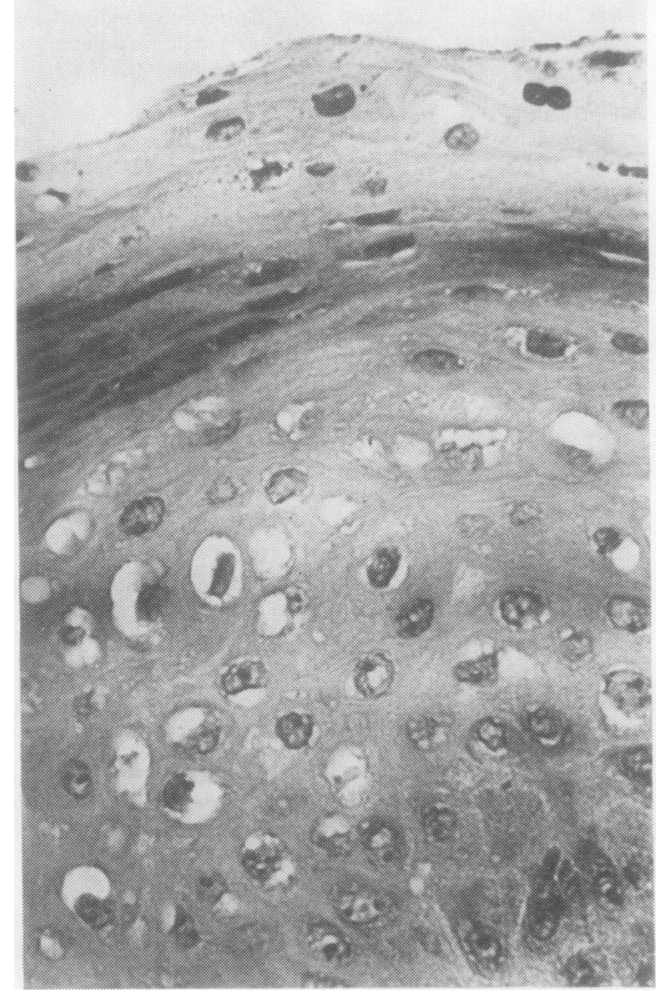

Fig. 6 Case 2. Colposcopic biopsy. Surface parakeratosis with underlying vacuolated cells. Haemotoxylin and eosin $\times 400$ (case 8) in which the epithelium shows mild to moderate dysplasia (CIN I-II) with surface은 koilocytosis.

3. Multiple viral warts occur elsewhere in the body $\stackrel{5}{\stackrel{5}{9}}$ and multiple condylomata, affecting the vulva and vagina as well as cervix are not unexpected (cases $1, \frac{\overline{\bar{c}}}{\bar{\rho}}$ $3,4,9$ and 10) but it is of interest that this series $\vec{\Phi}$ includes two cases with multifocal intraepithelial 2 neoplasia (cases 9 and 10).

The younger patient (case 10) had had intractable $\vec{\circ}$ vulval warts for seven years. She had failed to respond to a variety of treatments at another hospital $\vec{\omega}$ and was referred to St Mary's Hospital for simple? vulvectomy when vulval biopsy showed severe? dysplasia. Routine pre-operative colposcopy revealed ${ }_{+}^{\omega}$ no abnormality of the ectocervix but the endo-ir cervical canal and squamocolumnar junction could $N$ not be seen. The cervical smear contained immature dyskaryotic cells suggesting the presence of CIN III and this was confirmed by cone biopsy. Virus $\vec{\overrightarrow{ }}$ particles were seen in the cervical scrape material collected at the colposcopic examination.

The oldest patient in the group (case 9) had $\mathrm{a}_{\infty} \mathrm{\odot}$ hysterectomy in 1960 for carcinoma in situ of the cervix and, in 1970, a local excision of vulvalo carcinoma in situ. In 1976 the vulval lesion recurreds and in April 1978 a fringe of warty hyperkeratotic lesions appeared at the introitus. By September $1978^{\circ}$ the vaginal vault smear became abnormal and $\frac{\mathbb{Q}}{\Omega}$ colposcopic examination of the vagina revealed an area of flat, hyperkeratotic, Schiller-positive epi-윽 thelium on the right side involving the right cornu. This appearance persists and virus particles weres. seen in thin sections of scrape material taken from the vault in May 1979; these were identified aș papilloma virus by negative staining.

\section{Discussion}

IDENTIFICATION OF VIRUS PARTICLES Almeida, Howatson and Williams in $1962^{12}$ reviewe the literature concerning the identification of virus. particles in human skin warts and noted that of considerable range of particle diameters was reported by different authors who had examineक् ultra-thin sections stained by heavy metals. Theses measurements were consistently smaller than those made of negatively stained particles in aqueous ware extracts because of the shrinkage of tissue compo nents, including virus particles, that occurs during processing; the diameter of virus particles can be reduced by 15 to $20 \%$ in this way. In previoue reports of virus particles seen in cervical cons dylomatous lesions, ${ }^{2-4910}$ the morphologica $\$$ features of the particles were considered to b区 compatible with papilloma viruses but accurate 


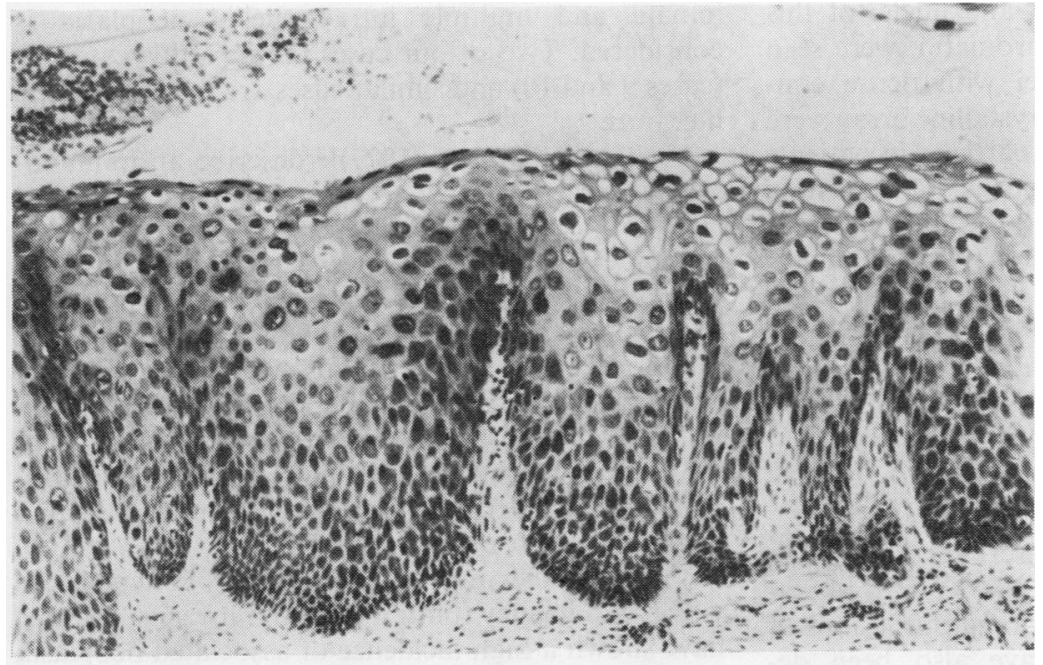

a

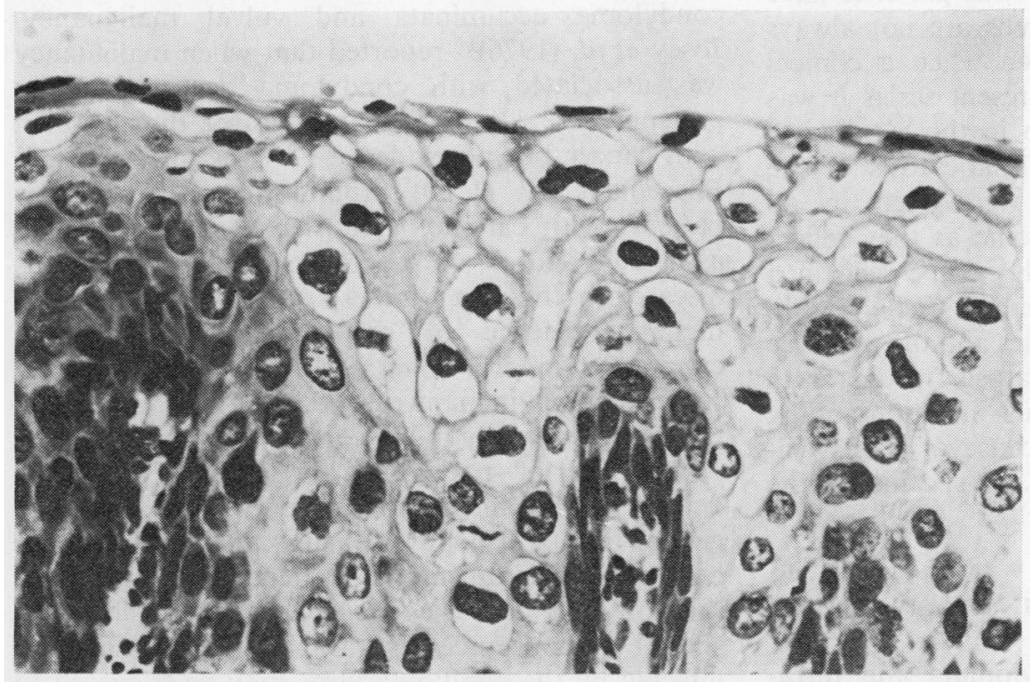

Fig. 7 (a) Case 8. Epithelium showing CIN I-II with surface koilocytosis. The nuclei are larger and more abnormal than those of the "simple" wart shown in Fig. 6. Haemotoxylin and eosin $\times 120$. (b) Detail of surface koilocytosis. Haemotoxylin and eosin $\times$ 280

b

measurements were not made using negatively stained material in a calibrated electron microscope. In two cases of the present series, accurate measurement of negatively stained viruses in a microscope calibrated with fixed catalase crystals showed that these were 50-62 $\mathrm{nm}$ (mean $57 \mathrm{~nm}$ ) in diameter and consistent with the size of papilloma viruses. In addition, these negatively stained particles were larger than particle measurements made from ultrathin sections of material from the same two patients. This result is in agreement with the findings of Almeida, Howatson and Williams. ${ }^{12}$
CONCENTRATION OF VIRUS PARTICLES

In this investigation virus particles were not found in $\mathbf{4 0}$ of the $\mathbf{5 0}$ patients studied although more than $50 \%$ of negative cases showed colposcopic, cytological or histological features which suggested a virus infection. When virus particles were seen only one or two virus-containing nuclei were present in each ultra-thin section. This is in agreement with the observations of Oriel and Almeida ${ }^{1}$ who pointed out that the concentration of virus particles was much lower in genital warts than in skin warts. These workers also commented on the scanty aggregates of 
virus particles in infected nuclei and nuclei of this type, with margination of the chromatin, were seen in the present series but nuclei with dense concentrations of virus particles in crystalline array were also found. The paucity of virus particles in patients infected by the papilloma virus means that screening with TEM is a time-consuming procedure and not realistic as a routine investigation. If preliminary identification of infected nuclei, using the immunoperoxidase reaction and Human Papilloma Virus antiserum, becomes possible, ${ }^{20}$ the test should be more accurate and more truly reflect the incidence of papilloma virus infection of the cervix.

\section{KOILOCYTOSIS AND DYSKERATOSIS}

In 1976 Meisels and Fortin ${ }^{5}$ described the association of koilocytosis ("balloon cells") and dyskeratosis in a clean smear with condylomatous lesions of the cervix. Koilocytotic cells have also been described in the cervical smear in the presence of noncondylomatous lesions in which virus particles have been seen. ${ }^{2} 36$ However, these cells are not always found in the cervical smear even when a clinical condyloma is present. ${ }^{7}$ In the present series it was noted that koilocytosis was seen in the cytological smear when there was surface koilocytosis of the epithelium. Dyskeratotic cells were seen in all specimens but these are not specific as they reflect parakeratosis in the tissue which can be seen in a variety of conditions. Multinucleation was a feature in seven of the 10 cases in this series and the presence of multinucleation with dyskeratosis would seem to be a useful indicator of virus infection in the absence of koilocytosis but, because of its association with other virus infections, not specific for the papilloma virus.

THE PAPILLOMA VIRUS AND INTRAEPITHELIAL NEOPLASIA

The association of tissue condylomata and intraepithelial neoplasia is not in doubt, ${ }^{4-8}$ but it has not always been clear in these reports if condylomatous changes were seen in the intraepithelial neoplasia or in adjacent epithelium. However, Purola and Savia ${ }^{7}$ reported mild, moderate, and severe dysplasia showing some microscopic features of condyloma but without papillary formation. In the present series tissue koilocytosis was seen in sections in areas of CIN I and II (mild and moderate dysplasia) but at this early stage in the spectrum of intraepithelial neoplasia, transient changes due to virus infection could have been misdiagnosed. There is more support for the view that papilloma virus infection might be an aetiological factor in the development of cervical cancer when the association of persistent condy- lomata and multiple intraepithelial neoplasia is $\underline{\vec{\sigma}}$ considered. Two of our cases fell into this category (cases 9 and 10) and similar cases are reported in the literature.

Leckie and Cotton (1977) ${ }^{13}$ describe an immuno- 흘 suppressed patient who presented with clinical $\frac{\bar{c}}{\frac{5}{\sigma}}$ "warts" of the vulva and perineum and who was $\stackrel{\mathbb{Q}}{\varrho}$ subsequently found to have carcinoma in situ of both the vulva and cervix. Another case of interest is $\rightarrow$ described by Woodruff et al. (1969) 14 the patient had multifocal neoplasia of the lower genital tract and, $\overrightarrow{\vec{\omega}}$ although the possibility of papilloma virus infection $\stackrel{5}{\circ}$ was not mentioned, the colposcopic appearance of $\frac{0}{8}$ the cervix resembled the flat, atypical condylo- $\omega$ matous lesions from which we have demonstrated of papilloma viruses.

Vulval studies are also important. Patients with $\stackrel{N}{\oplus}$ vulval malignancy (both in situ and invasive disease)을 have shown a high incidence of associated neoplasia elsewhere in the genital tract ranging from 10 to 3 $27 \% \%^{15-18}$ and there is also an association between 2 condyloma accuminata and vulval malignancy. $\overrightarrow{0}$ Josey et al. $(1976)^{19}$ reported that when malignancy was associated with condyloma accuminata the patients were 11 to 15 years younger than women with cancer but no evidence of virus infection and Buscema et al. $(1980)^{18}$ found that $20 \%$ of their patients with carcinoma in situ of the vulva had응 associated gross or microscopic condylomatous $\stackrel{\varrho}{\rightarrow}$ disease. In the first of these studies ${ }^{19}$ there was a을 higher incidence of condylomata with vulval ${ }^{3}$ carcinoma in situ than with invasive carcimona suggesting that in many cases there is no progression this may also apply in the cervix.

The role of papilloma virus infection in the development of intraepithelial neoplasia of the lower 3 . genital tract and finally invasive cancer is uncertain but there is circumstantial evidence to suggest that $₹$ this could happen. It could be postulated that undero special circumstances, natural or iatrogenic, cells infected by the papilloma virus may be triggered to을 become neoplastic. Evidence of infection with the papilloma virus could form the basis for selection of a group of women for careful follow-up using 0 cytology, colposcopy and directed biopsy which, in స్ట time, might resolve some aspects of the naturato history of cervical cancer.

\section{References}

1 Oriel JD, Almeida JD. Demonstration of virus particles inp human genital warts. Br J Vener Dis $1970 ; 46: 37-42$.

${ }^{2}$ Laverty CR, Russell P, Hills E, Booth N. The significance्? of noncondylomatous wart virus infection of the cervicab transformation zone. A review with discussion of tw illustrative cases. Acta Cytol 1978;22:195-201.

${ }^{3}$ Laverty CR, Booth N, Hills E, Cossart Y, Wills EJ尺 
Noncondylomatous wart virus infection of the postmenopausal cervix. Pathology 1978;10:373-8.

4 Della Torre G, Pilotti S, De Palo G, Rilke F. Viral particles in cervical condylomatous lesions. Tumori 1978; 64:549-53.

${ }^{5}$ Meisels A, Fortin R. Condylomatous lesions of the cervix and vagina I. Cytologic patterns. Acta Cytol 1976;20: 505-9.

- Meisels A, Fortin R, Roy N. Condylomatous lesions of the cervix II. Cytologic, colposcopic and histopathologic study. Acta Cytol 1977;21:379-90.

${ }^{7}$ Purola E, Savia E. Cytology of gynecologic condyloma acuminatum. Acta Cytol 1977;21:26-31.

${ }^{8}$ Syrjänen KJ. Morphologic survey of the condylomatous lesions in dysplastic and neoplastic epithelium of the uterine cervix. Arch Gynecol 1979;227:153-61.

- Hills E, Laverty CR. Electron microscopic detection of papilloma virus particles in selected koilocytotic cells in a routine cervical smear. Acta Cytol 1979;23:53-6.

${ }^{10}$ Morin C, Meisels A. Human papilloma virus infection of the uterine cervix. Letter to the editor, Acta Cytol 1980; 24:82-4.

11 Stanbridge CM, Butler EB, Langley FA. Problems in cervico-vaginal cytology: Fine structure as an aid to diagnosis. Acta Cytol 1980;24:335-43.

12 Almeida JD, Howatson AF, Williams MG. Electron microscope study of human warts; sites of virus production and nature of the inclusion bodies. $J$ Invest Dermatol $1962 ; 38: 337-45$.
13 Leckie GB, Cotton RE. Simultaneous in situ carcinoma of the cervix, vulva and perineum after immunosuppressive therapy for renal transplantation. Br J Obstet Gynaecol 1977;84:143-8.

14 Woodruff JD, Davis HJ, Jones HJ, Recio RG, Salimi R, Park I. Correlated investigative techniques of multiple anaplasias in the lower genital canal. Obstet Gynecol 1969;33:609-16.

${ }^{15}$ Hansen LH, Collins CG. Multicentric squamous cell carcinomas of the lower female genital tract. Am J Obstet Gynecol 1967;98:982-6.

16 Mickal A, Andonie JA, Dougherty CM. Squamous cell carcinoma of the vulva. Obstet Gynecol 1966;28:670-4.

${ }^{17}$ Franklin EW, Rutledge FD. Epidemiology of epidermoid carcinoma of the vulva. Obstet Gynecol 1972;39:165-72.

${ }^{18}$ Buscema J, Woodruff JD, Parmley TH, Genadry R. Carcinoma in situ of the vulva. Obstet Gynecol 1980;55: 225-30.

19 Josey WE, Nahmias AJ, Naib ZM. Viruses and cancer of the lower genital tract. Cancer 1976;38 supplement:52633.

${ }^{20}$ Woodruff JD, Braun L, Cavalieri R, Gupta P, Pass F, Shah KV. Immunologic identification of papillomavirus antigen in condyloma tissues from the female genital tract. Obstet Gynecol 1980;56:727-32.

Requests for reprints to: Dr CM Stanbridge, Cytology Laboratory, St Mary's Hospital, Manchester M13 0JH, England. 